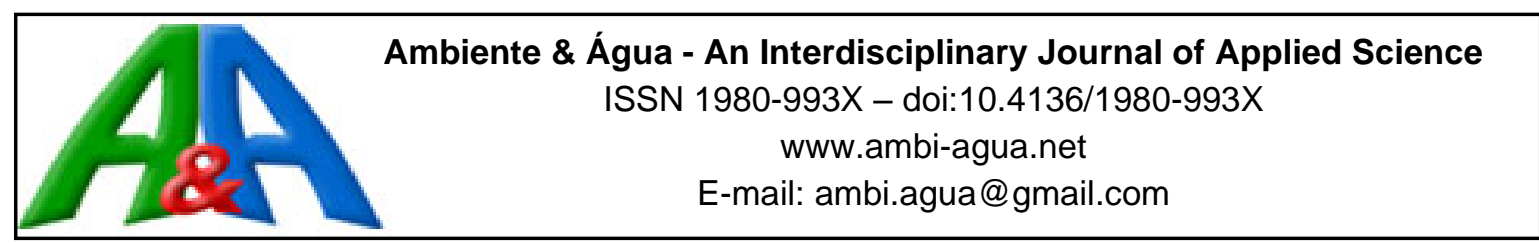

\title{
Chemical properties of an Oxisol affected by different land use and soil management systems
}

\author{
ARTICLES doi:10.4136/ambi-agua.2575
}

Received: 15 Sep. 2020; Accepted: 10 Nov. 2020

\begin{abstract}
Júlio César Ribeiro ${ }^{1 *(\mathbb{D})}$; Ana Aparecida da Silva Almeida ${ }^{2}$; Julio Cesar Raposo de Almeida ${ }^{2}$; João Luiz Gadiolii ${ }^{\circledR i}$; Marcos Gervasio Pereira ${ }^{1}$

${ }^{1}$ Departamento de Solos. Universidade Federal Rural do Rio de Janeiro (UFRRJ), Rodovia BR 465, km 07, CEP: 23890-000, Seropédica, RJ, Brazil. E-mail: mgervasiopereira01@ gmail.com

${ }^{2}$ Programa de Pós-Graduação em Ciências Ambientais (PPGCA). Universidade de Taubaté (UNITAU), Estrada Municipal Doutor José Luiz Cembranelli, n5000, CEP: 12081-010, Taubaté, SP, Brazil. E-mail: anaparecida.almeida@gmail.com, almeidajcr@gmail.com, jlgadioli@gmail.com "Corresponding author. E-mail: jcragronomo@gmail.com
\end{abstract}

\begin{abstract}
Agricultural crop management practices that guarantee soil quality are necessary for the sustainability of agrosystems. The use of agroforestry systems to make food production viable with less loss of soil fertility is a possible alternative for sustainable agriculture. This work evaluated the chemical characteristics of an Oxisol in three systems of use and management: 1) peach for palm heart production; 2) peach palm for fruit and seed production; and 3) Urochloa decumbens pasture. In these areas, located at Fazenda Piloto of the Agricultural Sciences Department at the University of Taubaté - UNITAU, Taubaté-SP, Brazil, samples were collected at the depths $0-10 \mathrm{~cm}, 10-20 \mathrm{~cm}$ and $20-40 \mathrm{~cm}$. In these soil samples, levels of $\mathrm{P}, \mathrm{K}$, $\mathrm{Ca}, \mathrm{Mg}, \mathrm{B}, \mathrm{Cu}, \mathrm{Fe}, \mathrm{Mn}, \mathrm{Zn}, \mathrm{pHCaCl}_{2}, \mathrm{H}+\mathrm{Al}$, total organic carbon and organic carbon stock were determined. The sums of bases (SB), cation exchange capacity (CEC) and base saturation (BS) were calculated. The results were subjected to analysis of variance and the means were compared using the Tukey test at 5\%. The results indicate that soil cultivated with peach palm for palm heart production showed better fertility compared to peach palm for fruit and seed production and pasture. The upper layers $0-10 \mathrm{~cm}$ and $10-20 \mathrm{~cm}$ are the most fertile, concentrating $\mathrm{P}, \mathrm{Ca}$ e $\mathrm{Mg}$, high $\mathrm{CEC}, \mathrm{SB}$ and $\mathrm{BS}$.
\end{abstract}

Keywords: Bactris gasipaes Kunth, pasture, soil fertility, Urochloa decumbens.

\section{Características químicas de um Latossolo Vermelho Amarelo sob diferentes sistemas de uso e manejo}

\section{RESUMO}

As práticas de manejo das culturas agrícolas que garantam a qualidade do solo são necessárias para a sustentabilidade dos agrossistemas. $\mathrm{O}$ uso de sistemas agroflorestais para viabilizar a produção de alimentos, proporcionando menor redução da fertilidade do solo é uma alternativa possível para uma agricultura sustentável. Este trabalho teve por objetivo avaliar as características químicas de um Latossolo Vermelho-Amarelo em três sistemas de uso e manejo: 1) pupunha para produção de palmitos, 2) pupunha para produção de frutos e sementes e 3) pastagem de Urochloa decumbens em pousio. Nessas áreas, localizadas na Fazenda Piloto do 
Júlio César Ribeiro et al.

Departamento de Ciências Agrárias da Universidade de Taubaté - UNITAU, Taubaté-SP, Brasil, foram realizadas coletas do solo nas profundidades de $0-10 \mathrm{~cm}, 10-20 \mathrm{~cm}$ e $20-40 \mathrm{~cm}$. Nessas amostras de solo foram determinados os teores biodisponíveis de P, K, Ca, Mg, B, Cu, $\mathrm{Fe}, \mathrm{Mn}, \mathrm{Zn}, \mathrm{pHCaCl}_{2}, \mathrm{H}+\mathrm{Al}$, carbono orgânico total e estoque de carbono orgânico. A soma de bases (SB), a capacidade de troca catiônica (CTC) e a saturação por bases (V) foram calculadas. Os resultados foram submetidos à análise de variância e as médias foram comparadas pelo teste de Tukey a 5\%. O solo cultivado com pupunha para produção de palmito apresentou melhor fertilidade, comparado a pupunha para produção de frutos e sementes e a pastagem. As camadas superiores de $0-10 \mathrm{~cm}$ e $10-20 \mathrm{~cm}$ são as mais férteis, concentrando macronutrientes e maiores CTC, SB e V.

Palavras-chave: Bactris gasipaes Kunth, fertilidade do solo, pastagem, Urochloa decumbens.

\section{INTRODUCTION}

Agricultural, livestock and forestry activities, when handled improperly, cause changes in the respective agrosystems, either by depleting of mineral elements in the soil or by reducing organic matter.

It is a great challenge to develop and maintain agricultural production systems with high productivity and environmental sustainability, especially in tropical regions, where soils present a high degree of weathering (Netto et al., 2009).

In highly weathered soils, organic matter becomes essential for maintaining or improving soil chemical quality, promoting cation retention, providing nutrients to plants, as well as complexing toxic elements (Portugal et al., 2010; Schiavo et al., 2011).

Soil quality has been continuously improving since the publication of the report "Soil and water quality - an agenda for agriculture" (NRCC, 1993). Among its different approaches, the report highlights the use of indicators related to soil functionality is an indirect way of measuring soil quality. Here the functionality characteristics would be related to the supply of nutrients and water to the plants, as well as nutrient cycling (Araújo et al., 2012).

Freitas et al. (2017) highlight that the study of soils' chemical properties, in addition to allowing the understanding of present fertility, makes it possible to observe possible changes suffered due to the management adopted in the area, and are therefore good soil quality indicators. These include acidity, salinity, organic matter, calcium, magnesium, potassium levels, available phosphorus, ion exchange capacity (Maia et al., 2013; Morais et al., 2015), carbon total and stock values (Almeida et al., 2016).

In several Brazil regions, peach palm cultivation (Bactris gasipaes) has become an important income source (Silva et al., 2007; Fernandes et al., 2013), given its potential for producing palm hearts and fruits. Proper crop residue management can improve physical and chemical soil characteristics, provide protection against erosion, and increase soil fertility (Souza and Piña-Rodrigues, 2013). Litterfall is the main pathway for nutrient transfer to the soil. Ribeiro et al. (2020) observed that this plantation produced $9.2 \mathrm{Mg} \mathrm{ha}^{-1}$ of litter, which once decomposed provides the return of significant amounts of $\mathrm{N}, \mathrm{P}, \mathrm{K}, \mathrm{Ca}$, and $\mathrm{Mg}$ to the soil.

Another way to promote the supply of biomass to the soil is the implantation of pastures, which in most cases replace native vegetation with pasture planted under continuous grazing, affecting soil chemical quality, since inadequate management of these is common in areas after their formation (Cardoso et al., 2011).

In the formation of Brazilian pastures, Urochloa grass is widely used, given the adaptability of this species to various edaphoclimatic conditions, growing well in acidic and infertile soils, as well as being a disease-resistant (Kluthcouski et al., 2013). It also has a high production capacity and continuously renews its root system, which can improve soil over time 
by increasing soil organic matter and, consequently, soil fertility.

In this context, as soil is a complex and dynamic natural resource, the objective of this study was to evaluate the chemical properties of a Oxisol in three use and management systems: (1) peach palm for palm heart production; (2) peach palm for fruit and seed production; and, (3) Urochloa decumbens pasture in fallow. The study also evaluated the contribution of each system to the gradient of chemical attributes at depths of $0-10,10-20$, and $20-40 \mathrm{~cm}$, where greater presence of roots of these plants is found.

\section{MATERIAL AND METHODS}

The study was carried out in an Oxisol area (Santos et al., 2018), located at Fazenda Piloto of the Agricultural Sciences Department at the University of Taubaté - UNITAU, Taubaté-SP, Brazil, coordinates $23^{\circ} 01^{\prime} \mathrm{S}$ and $45^{\circ} 30^{\prime} \mathrm{W}, 565 \mathrm{~m}$ altitude, with an average annual rainfall of $1,350 \mathrm{~mm}$ and an average temperature of $21.9^{\circ} \mathrm{C}$ (Folhes and Fisch, 2006).

In 1998, a Urochloa decumbens pasture was subdivided into sub-areas for installation of experiments to evaluate the chemical properties of an oxisol in three use and management systems (Figure 1).
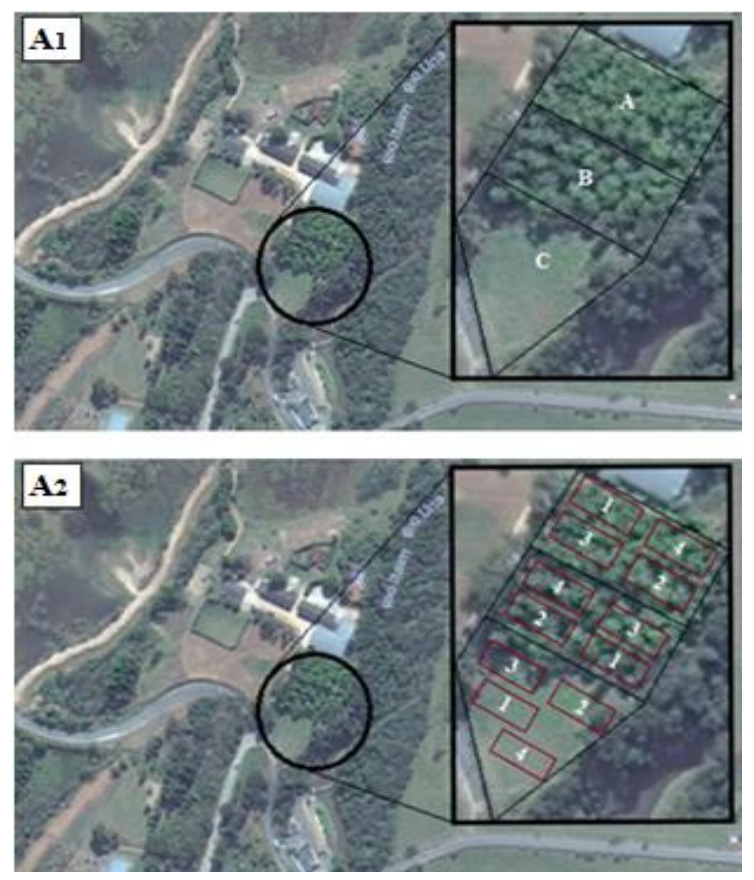

Figure 1. $\left(A_{1}\right)$ The arrangement of evaluated treatments. (A) Peach palm for fruit and seed production; (B) Peach palm for production of hearts of palm; (C) Urochloa decumbens pasture in fallow. $\left(\mathrm{A}_{2}\right)$ Distribution of sub-areas.

The area for planting of peach palm was plowed and lime was added to the entire area. After 45 days, each plant was planted in pits, with spacing of $2 \times 1$ meters.

The rest of the Urochloa pasture remained without any type of mineral fertilization. The average size of each system under study was 0.5 ha. The systems were subjected to frequent clearings, with all biomass kept in place.

Each year fertilizer was used for production of peach palm for palm hearts with $100 \mathrm{~kg} \mathrm{ha}^{-1}$ of ammonium sulfate and $40 \mathrm{~kg} \mathrm{ha}^{-1}$ of potassium chloride; and every three years, fertilization was with $30 \mathrm{~kg} \mathrm{ha}^{-1}$ of simple superphosphate and $2 \mathrm{~kg} \mathrm{ha}^{-1}$ of borax. The fertilization was done in a total area, and all residues from the annual extraction of palm hearts were mixed into the soil. However, for the production of peach palm for fruits and seeds, 
fertilization, in total area, was made every three years, with $2 \mathrm{~kg} \mathrm{ha}^{-1}$ of borax.

The experimental design used was completely randomized with the treatments (1) peach palm for palm heart production; (2) peach palm for fruit and seed production; and, (3) Urochloa decumbens pasture - the control soil management system because there was no soil correction and fertilization (Figure 1).

In each experimental plot, after 15 years of peach palm plantation, 10 simple sub-samples with four repetitions per system were collected with a drill auger for carrying out chemical analysis. This procedure was performed for samples collected at depths of 0-10, 10-20 and 20$40 \mathrm{~cm}$. Each sample was dried in the shade, ground and sieved $(2 \mathrm{~mm})$, and subsequently analyzed for $(\mathrm{pH})$ in $\mathrm{CaCl}_{2}$, potential acidity $(\mathrm{H}+\mathrm{Al})$, total organic carbon (TOC), phosphorus (P) in resin, $\mathrm{K}, \mathrm{Ca}, \mathrm{Mg}, \mathrm{Fe}, \mathrm{Cu}, \mathrm{Mn}, \mathrm{Zn}$ and $\mathrm{B}$ contents according to van Raij et al. (2001). These analyses were performed at the Laboratory of Soil Analysis and Plant Nutrition of the Department of Agricultural Sciences at the University of Taubaté - UNITAU, Taubaté-SP, Brazil.

From these results, the values of the sum of bases (SB), cation exchange capacity at $\mathrm{pH}$ 7.0 (CEC), base saturation (BS\%) and the relationship between the elements that make up the $\mathrm{CEC}, \mathrm{K} / \mathrm{CEC}, \mathrm{Ca} / \mathrm{CEC}$, and $\mathrm{Mg} / \mathrm{CEC}$ were calculated.

The results were subjected to analysis of variance by F test $(\rho \leq 0.05)$ to detect differences in all factors and the comparison between the means by the Tukey test $(\rho \leq 0.05)$ using the SAS statistical software (SAS Institute, 1999).

\section{RESULTS AND DISCUSSION}

The analysis of variance showed that the soil use and management systems and the depths showed significance $(\rho \leq 0.05)$ for most of the analyzed chemical attributes. However, there was no significant interaction between land-use and management systems and depths (Table 1).

Table 1. Summary of the results of the analysis of variance $(p<0.05)$ for the chemical properties of an Oxisol as a function of the different management systems (peach palm for production of fruits and seeds, peach palm for production of palm hearts, and pasture of Urochloa decumbens) and depths $(0-10 \mathrm{~cm}, 10-20 \mathrm{~cm}$ and $20-40 \mathrm{~cm})$.

\begin{tabular}{lccccccccc}
\hline & \multicolumn{10}{c}{$\rho$ valor } \\
\cline { 2 - 10 } Factor & $\mathrm{pH}$ & $\mathrm{P}$ & $\mathrm{K}$ & $\mathrm{Ca}$ & $\mathrm{Mg}$ & $\mathrm{H}+\mathrm{Al}$ & $\mathrm{SB}$ & $\mathrm{CEC}$ & $\mathrm{BS}$ \\
\hline Systems(A) & $0.007^{*}$ & $0.001^{*}$ & $0.002^{*}$ & $0.002^{*}$ & $0.028^{*}$ & $0.004^{*}$ & $0.005^{*}$ & $0.015^{*}$ & $0.010^{*}$ \\
Depths (B) & $0.008^{*}$ & $0.361^{\mathrm{ns}}$ & $0.007^{*}$ & $0.358^{\mathrm{ns}}$ & $0.011^{*}$ & $0.035^{*}$ & $0.140^{\mathrm{ns}}$ & $0.254^{\mathrm{ns}}$ & $0.026^{*}$ \\
$\mathrm{~A} \mathrm{x} \mathrm{B}$ & $0.801^{\mathrm{ns}}$ & $0.849^{\mathrm{ns}}$ & $0.519^{\mathrm{ns}}$ & $0.909^{\mathrm{ns}}$ & $0.734^{\mathrm{ns}}$ & $0.521^{\mathrm{ns}}$ & $0.889^{\mathrm{ns}}$ & $0.861^{\mathrm{ns}}$ & $0.863^{\mathrm{ns}}$ \\
\hline $\mathrm{CV}(\%)$ & 6.05 & 100.00 & 28.99 & 44.94 & 25.52 & 14.00 & 35.05 & 17.85 & 18.79 \\
\hline & $\mathrm{B}$ & $\mathrm{Cu}$ & $\mathrm{Fe}$ & $\mathrm{Mn}$ & $\mathrm{Zn}$ & $\mathrm{K} / \mathrm{CEC}$ & $\mathrm{Ca} / \mathrm{CEC}$ & $\mathrm{Mg} / \mathrm{CEC}$ & \\
\hline Systems$(\mathrm{A})$ & $0.032^{*}$ & $0.001^{*}$ & $0.201^{\mathrm{ns}}$ & $0.266^{\mathrm{ns}}$ & $0.001^{*}$ & $0.021^{*}$ & $0.002^{*}$ & $0.057^{\mathrm{ns}}$ & \\
Depths $(\mathrm{B})$ & $0.515^{\mathrm{ns}}$ & $0.001^{*}$ & $0.001^{*}$ & $0.001^{*}$ & $0.256^{\mathrm{ns}}$ & $0.135^{\mathrm{ns}}$ & $0.152^{\mathrm{ns}}$ & $0.003^{*}$ & \\
$\mathrm{~A} \mathrm{x} \mathrm{B}$ & $0.499^{\mathrm{ns}}$ & $0.24^{\mathrm{ns}}$ & $0.673^{\mathrm{ns}}$ & $0.961^{\mathrm{ns}}$ & $0.911^{\mathrm{ns}}$ & $0.673^{\mathrm{ns}}$ & $0.811^{\mathrm{ns}}$ & $0.898^{\mathrm{ns}}$ & \\
\hline $\mathrm{CV}(\%)$ & 26.45 & 18.99 & 16.14 & 24.81 & 107.06 & 30.21 & 26.53 & 15.66 \\
\hline
\end{tabular}

$\mathrm{pH}$ in $\mathrm{CaCl}_{2}$ at a ratio of 1:2.5 v/v. $\mathrm{Ca}^{2+}, \mathrm{Mg}^{2+}$ and $\mathrm{Al}^{3+}$ extracted with $\mathrm{KCl}$ solution $\left(1 \mathrm{~mol} \mathrm{~L}^{-1}\right)$; $\mathrm{P}$ and $\mathrm{K}$ extracted with Mehlich1; $\mathrm{H}+\mathrm{Al}=\mathrm{SMP}$ buffer solution $-\mathrm{pH} 7.5 ; \mathrm{CEC}$ at $\mathrm{pH} 7.0 ; \mathrm{SB}=$ sum of base; $\mathrm{BS}=$ base saturation. $\mathrm{Cu}^{2+}, \mathrm{Mn}^{2+}$ and $\mathrm{Al}^{3+}$ extracted with DTPA solution $\left(1 \mathrm{~mol} \mathrm{~L}^{-}\right.$ 1)

* - significant $(\mathrm{p}<0.05) ;{ }^{\mathrm{ns}}$ - não significativo. $\mathrm{CV}=$ coefficient of variation.

* - significant $(\mathrm{p}<0,05) ;{ }^{\mathrm{ns}}$-não significativo. $\mathrm{CV}=$ coefficient of variation. 
Soil chemical properties presented variability, with peach palm for production of palm hearts being the best system compared to the others (Table 2). Regardless of the management system, the $\mathrm{pH}$ and $\mathrm{H}+\mathrm{Al}$ values found characterize the soil as medium- to high-acidity (Raij et al., 1997).

We observed a reduction in the potential for acidity and consequently an increase in $\mathrm{pH}$ in the peach palm system for the production of hearts of palm. The lower $\mathrm{pH}$ and high potential acidity in peach palm for fruit and seed production cause the need to correct acidity in long plantings. Pasture, our control system, reflected the lack of soil correction and basic fertilization by other authors such as Benites et al. (2010); Butzke et al. (2020); Guareschi et al. (2012); Lourente et al. (2011).

Table 2. Chemical properties of an Oxisol as a function of management systems (peach palm for production of fruits and seeds, peach palm for production of palm heart, and pasture of Urochloa decumbens).

\begin{tabular}{lccccccccc}
\hline \multirow{2}{*}{ Systems } & $\mathrm{pH}$ & $\mathrm{P}$ & $\mathrm{K}$ & $\mathrm{Ca}$ & $\mathrm{Mg}$ & $\mathrm{H}+\mathrm{Al}$ & $\mathrm{SB}$ & $\mathrm{CEC}$ & $\mathrm{BS}$ \\
\cline { 2 - 11 } & \multicolumn{7}{c}{$\mathrm{mg} \mathrm{kg-}^{1}$} & \multicolumn{7}{c}{$\mathrm{cmolc} \mathrm{dm-}^{-3}$} & & & $\%$ \\
\hline Fruits and seeds & $4.86 \mathrm{~b}$ & $5.67 \mathrm{~b}$ & $0.17 \mathrm{~b}$ & $1.48 \mathrm{~b}$ & $0.79 \mathrm{~b}$ & $2.30 \mathrm{a}$ & $2.45 \mathrm{~b}$ & $4.75 \mathrm{~b}$ & $50.91 \mathrm{~b}$ \\
Palm heart & $5.27 \mathrm{a}$ & $31.58 \mathrm{a}$ & $0.22 \mathrm{ab}$ & $2.77 \mathrm{a}$ & $1.03 \mathrm{ab}$ & $1.94 \mathrm{~b}$ & $4.02 \mathrm{a}$ & $5.96 \mathrm{a}$ & $64.94 \mathrm{a}$ \\
Pasture & $4.96 \mathrm{~b}$ & $10.33 \mathrm{~b}$ & $0.27 \mathrm{a}$ & $1.68 \mathrm{~b}$ & $1.04 \mathrm{a}$ & $2.38 \mathrm{a}$ & $2.99 \mathrm{ab}$ & $5.36 \mathrm{ab}$ & $54.89 \mathrm{ab}$ \\
Mean & 5.03 & 15.86 & 0.22 & 1.98 & 0.96 & 2.21 & 3.15 & 5.36 & 56.91 \\
SMD & 0.31 & 16.06 & 0.06 & 0.89 & 0.25 & 0.31 & 1.12 & 0.97 & 10.82 \\
\hline & $\mathrm{B}$ & $\mathrm{Cu}$ & $\mathrm{Fe}$ & $\mathrm{Mn}$ & $\mathrm{Zn}$ & $\mathrm{K} / \mathrm{CEC}$ & $\mathrm{Ca} / \mathrm{CEC}$ & $\mathrm{Mg} / \mathrm{CEC}$ & \\
\hline & & & $\mathrm{mg} \mathrm{kg}-1$ & & & & $\%$ & & \\
\hline Fruits and seeds & $0.20 \mathrm{ab}$ & $1.04 \mathrm{~b}$ & $57.17 \mathrm{a}$ & $13.53 \mathrm{a}$ & $1.04 \mathrm{~b}$ & $3.57 \mathrm{~b}$ & $30.85 \mathrm{~b}$ & $16.49 \mathrm{a}$ & \\
Palm hearts & $0.23 \mathrm{a}$ & $2.33 \mathrm{a}$ & $53.42 \mathrm{a}$ & $15.99 \mathrm{a}$ & $5.69 \mathrm{a}$ & $3.87 \mathrm{ab}$ & $43.96 \mathrm{a}$ & $17.11 \mathrm{a}$ & \\
Pasture & $0.17 \mathrm{~b}$ & $1.19 \mathrm{~b}$ & $60.33 \mathrm{a}$ & $15.18 \mathrm{a}$ & $1.29 \mathrm{~b}$ & $5.01 \mathrm{a}$ & $30.67 \mathrm{~b}$ & $19.21 \mathrm{a}$ & \\
Mean & 0.20 & 1.52 & 56.97 & 14.90 & 2.68 & 4.15 & 35.16 & 17.60 & \\
SMD & 0.05 & 1.75 & 2.65 & 3.74 & 2.90 & 1.27 & 9.45 & 2.79 & \\
\hline
\end{tabular}

SMD significant minimum difference.

Means followed by the same letters in a column do not differ significantly by the Tukey test $(p<0.05)$.

The fertility results, considering the assessments made at depths of $0-10 \mathrm{~cm}, 10-20 \mathrm{~cm}$ and $20-40 \mathrm{~cm}$ of the three management systems are shown in Table 3.

The upper layer $(0-10 \mathrm{~cm})$ presents an intermediate value of $\mathrm{H}+\mathrm{Al}$, and does not differ from the other layers analyzed. The depths of $0-10 \mathrm{~cm}, 10-20 \mathrm{~cm}$ and $20-40 \mathrm{~cm}$ showed lower $(2.07$ cmolc dm- $\left.{ }^{3}\right)$ and higher $\left(2.40 \mathrm{cmolc} \mathrm{dm}^{3}\right)$ values, respectively. The $\mathrm{pH}$ in the superficial layers $(0-10 \mathrm{~cm}, 10-20 \mathrm{~cm})$ did not differ significantly. The deepest layer $(20-40 \mathrm{~cm})$ presented a lower $\mathrm{pH}$ value (4.79). The increase in potential acidity and reduction of $\mathrm{pH}$ in depth were also verified in other studies carried out in Oxisol under different management systems (Guareschi et al., 2012; Montanari et al., 2016; Portugal et al., 2010; Schiavo et al., 2011).

The upper layers, $0-10 \mathrm{~cm}$ and $10-20 \mathrm{~cm}$ are the most fertile, concentrating P, Ca e $\mathrm{Mg}$, high CEC, SB and BS (Table 2).

The peach palm for the production of fruits and seeds and pasture of Urochloa decumbens systems showed low levels of $\mathrm{P}$ and $\mathrm{Ca}$. In the fruit and seed production system, we observe that dynamics of mineral cycling and availability for the soil solution was not sufficient to maintain or improve the chemical conditions of the soil compared to pasture. We therefore recommended corrective practices in this management for soil enrichment, whether in chemical or organic form, as suggested by Butzke et al. (2020) and Silva et al. (2011). 
Table 3. Chemical properties of Oxisol fertility of different management systems, at the depths of 0$10 \mathrm{~cm}, 10-20 \mathrm{~cm}$ and $20-40 \mathrm{~cm}$.

\begin{tabular}{|c|c|c|c|c|c|c|c|c|c|}
\hline \multirow{2}{*}{ Depth } & $\mathrm{pH}$ & $\mathrm{P}$ & $\mathrm{K}$ & $\mathrm{Ca}$ & $\mathrm{Mg}$ & $\mathrm{H}+\mathrm{Al}$ & SB & CEC & $\mathrm{BS}$ \\
\hline & & mg kg-1 & \multicolumn{6}{|c|}{ cmolc dm- $^{3}$} & $\%$ \\
\hline $0-10 \mathrm{~cm}$ & $5.19 \mathrm{a}$ & $20.50 \mathrm{a}$ & $0.27 \mathrm{a}$ & $2.18 \mathrm{a}$ & $1.11 \mathrm{a}$ & $2.15 \mathrm{ab}$ & $3.55 \mathrm{a}$ & $5.70 \mathrm{a}$ & $61.20 \mathrm{a}$ \\
\hline $10-20 \mathrm{~cm}$ & $5.10 \mathrm{a}$ & $16.00 \mathrm{a}$ & $0.20 \mathrm{~b}$ & $2.07 \mathrm{a}$ & $0.98 \mathrm{ab}$ & $2.07 \mathrm{~b}$ & $3.25 \mathrm{a}$ & $5.32 \mathrm{a}$ & $59.87 \mathrm{ab}$ \\
\hline $20-40 \mathrm{~cm}$ & $4.79 b$ & $11.08 \mathrm{a}$ & $0.19 b$ & $1.68 \mathrm{a}$ & $0.78 b$ & $2.40 \mathrm{a}$ & $2.64 a$ & $5.04 \mathrm{a}$ & $49.67 b$ \\
\hline Mean & 5.03 & 15.86 & 0.22 & 1.98 & 0.96 & 2.21 & 3.15 & 5.36 & 56.91 \\
\hline \multirow[t]{3}{*}{ SMD } & 0.31 & 16.06 & 0.06 & 0.89 & 0.25 & 0.31 & 1.12 & 0.97 & 10.82 \\
\hline & B & $\mathrm{Cu}$ & $\mathrm{Fe}$ & $\mathrm{Mn}$ & $\mathrm{Zn}$ & K/CEC & $\mathrm{Ca} / \mathrm{CEC}$ & $\mathrm{Mg} / \mathrm{CEC}$ & \\
\hline & & \multicolumn{3}{|c|}{ mg kg-1 } & \multicolumn{5}{|c|}{$\%$} \\
\hline $0-10 \mathrm{~cm}$ & $0.21 \mathrm{a}$ & $2.25 \mathrm{a}$ & $71.08 \mathrm{a}$ & $21.07 \mathrm{a}$ & $3.44 \mathrm{a}$ & $4.76 \mathrm{a}$ & $37.17 \mathrm{a}$ & $19.28 \mathrm{a}$ & \\
\hline $10-20 \mathrm{~cm}$ & $0.19 \mathrm{a}$ & $1.36 \mathrm{a}$ & $59.83 b$ & $16.24 \mathrm{~b}$ & $3.03 \mathrm{a}$ & $3.92 \mathrm{a}$ & $37.57 \mathrm{a}$ & $18.37 \mathrm{a}$ & \\
\hline $20-40 \mathrm{~cm}$ & $0.20 \mathrm{a}$ & $0.96 \mathrm{~b}$ & $40.0 \mathrm{c}$ & $7.39 \mathrm{c}$ & $1.56 \mathrm{a}$ & $3.77 \mathrm{a}$ & $30.75 a$ & $15.15 b$ & \\
\hline Mean & 0.20 & 1.52 & 56.97 & 14.90 & 2.68 & 4.15 & 35.16 & 17.60 & \\
\hline SMD & 0.05 & 1.75 & 2.65 & 3.74 & 2.90 & 1.27 & 9.45 & 2.79 & \\
\hline
\end{tabular}

SMD significant minimum difference.

Means followed by the same letters in a column do not differ significantly by the Tukey test $(p<0.05)$.

The peach palm heart palm management system showed high and medium $\mathrm{P}$ and $\mathrm{Ca}$ levels, respectively (Raij et al., 1997), that are justified by the use of maintenance fertilizers combined with greater nutrient cycling promoted by the cutting of the hearts of palm, since the biomass from the extraction was kept under the soil. Schiavo et al. (2011) and Iwata et al. (2012) verified the increase in $\mathrm{P}$ and $\mathrm{Ca}$ soil levels management systems under which the biomass was kept under the soil without disturbance, which justified the tendency for the $\mathrm{P}$ and $\mathrm{Ca}$ gradients in depth.

The $\mathrm{K}$ and $\mathrm{Mg}$ soil levels were higher in the pasture system and lower in the peach palm system for the production of fruits and seeds (Table 2). This is understandable, since the pasture was not grazed for at least 15 years, that is a condition of less export of these nutrients, as pointed out by Benites et al. (2010).

The CEC was low in all systems under study similar compared to those observed by Tavares-Filho et al. (2011) in a study of soil fertility of pastures submitted to different management for more than a decade. In the Urochloa decumbens pasture, CEC was $5.36 \mathrm{cmolc}$ $\mathrm{dm}^{-3}$, which is similar $\left(5.4 \mathrm{cmolc} \mathrm{dm}{ }^{-3}\right)$ to that verified by the same authors in a pasture system with grazed native Urochloa decumbens that were exposed to burns every 3 years.

BS was over $50 \%$ in all evaluated systems. Therefore, eutrophic soil with a slight gradient in depth, which is desirable for the good development of both peach palm and Urochloa decumbens (Raij et al., 1997). The results are similar to the studies that observed an increase in the nutrients availability over time with the enrichment of the superficial layers of the soil due to the constant supply of organic matter (Butzke et al., 2020; Iwata et al., 2012; Montanari et al., 2016). Except for $\mathrm{Mg} / \mathrm{CEC}$, the other relationships showed variation between the evaluated systems. But, despite these variations, Ca was the nutrient that contributed most to CEC, followed by $\mathrm{Mg}$ and $\mathrm{K}$ (Tables 2 and 3).

The results in Table 4 show that there was no significant interaction for the total organic carbon content between the land-use and management systems and the depths, despite a tendency to decrease in depth. 
Table 4. Total organic carbon and carbon stock at different depths of an Oxisol depending on the management systems: 1) peach palm for fruit and seed production; 2) peach palm for the production of hearts of palm; and, 3) pasture of Urochloa decumbens.

\begin{tabular}{cccc}
\hline \multirow{2}{*}{ Depth } & \multicolumn{3}{c}{ Management systems } \\
\cline { 2 - 4 } & Fruits and seeds & Palm heart & Pasture \\
\hline \multicolumn{3}{c}{ Total organic carbon $\left(\mathrm{g} \mathrm{kg}^{-1}\right)$} \\
\hline $0-10 \mathrm{~cm}$ & $12.18 \mathrm{a}$ & $16.39 \mathrm{a}$ & $16.68 \mathrm{a}$ \\
$10-20 \mathrm{~cm}$ & $9.71 \mathrm{a}$ & $10.30 \mathrm{~b}$ & $11.60 \mathrm{~b}$ \\
$20-40 \mathrm{~cm}$ & $8.26 \mathrm{a}$ & $7.25 \mathrm{c}$ & $7.98 \mathrm{c}$ \\
Mean & 10.05 & 11.33 & 12.09 \\
CV $(\%)$ & 40.32 & 6.51 & 7.76 \\
\hline \multicolumn{3}{c}{ Carbon stock (Mg ha- $\left.{ }^{-1}\right)$} \\
\hline $0-20 \mathrm{~cm}$ & 20.78 & 23.20 \\
\hline
\end{tabular}

$\mathrm{CV}=$ coefficient of variation.

Means followed by the same letters in a column do not differ significantly by the Tukey test $(\mathrm{p}<0.05)$.

The total organic carbon was concentrated to a depth of $20 \mathrm{~cm}$, reflecting in carbon stocks of $20.78,23.20$, and $24.56 \mathrm{Mg} \mathrm{ha}^{-1}$ for the peach palm system for the production of fruits and seeds, peach palm for the production of palm hearts and pasture, respectively. The litter in the peach palm plantations proves this enrichment of the superficial layers of the soil, constantly adding new biomass (Ribeiro et al., 2020). Bernoux et al. (1999) found a significant increase in the carbon stock in a 15 year pasture $\left(26.5 \mathrm{Mg} \mathrm{ha}^{-1}\right)$, as in our study. Highest carbon stock was observed in the pasture, which corresponded with greater carbon storage $\left(63.5 \mathrm{Mg} \mathrm{ha}^{-1}\right)$ (Lopes et al., 2011). This greater carbon stock in pastures is because of the intense renewal of pasture root systems (Loss et al., 2014).

Pereira et al. (2010) found decreasing levels of total organic carbon in depths up to $20 \mathrm{~cm}$ in pasture area. However, these levels were lower than those verified in this study. According to the same authors, management systems in which the soil does not revolve contribute to the increase in organic carbon stock, particularly in the superficial layers, which improves both the physical and chemical characteristics of the soil, avoiding erosive processes over time.

\section{CONCLUSION}

The soil cultivated with peach palm for palm heart production showed better fertility compared to peach palm for fruit and seed production and pasture of Urochloa decumbens.

There was a higher concentration of nutrients and organic carbon in the depths $0-10 \mathrm{~cm}$ and $10-20 \mathrm{~cm}$.

\section{REFERENCES}

ALMEIDA, L. S. et al. Indicadores de qualidade do solo em cultivos irrigados de cana-deaçúcar. Pesquisa Agropecuária Brasileira, v. 51, n. 9, p. 1539-1547, 2016. https://dx.doi.org/10.1590/S0100-204X2016000900053

ARAÚJO, E. A. et al. Qualidade do solo: conceitos. indicadores e avaliação. Pesquisa Aplicada \& Agrotécnica, v. 5, p. 187-206, 2012. 
BENITES, V. M.; MOUTTA, R. O.; COUTINHO, H. L. C.; BALIEIRO, F. C. Análise discriminante de solos sob diferentes usos em área de mata atlântica a partir de atributos da matéria orgânica. Revista Árvore, v. 34, n. 4, p. 685-690, 2010. https://doi.org/10.1590/S0100-67622010000400013

BERNOUX, M. et al. Carbono e nitrogênio em solo de uma cronossequência de floresta tropical-pastagem de Paragominas. Scientia Agricola, v. 56, p. 777-783, 1999. https://doi.org/10.1590/S0103-90161999000400003

BUTZKE, A. G. et al. Soil fertility and organic carbon in two decades of agroforestry systems composed of Brazil nut, cupuaçuzeiro and peach palm in the Western Amazon. Científica, v. 48, n. 2, p. 160-169, 2020. http://dx.doi.org/10.15361/19845529.2020v48n2p160-169

CARDOSO, E. L. et al. Qualidade química e física do solo sob vegetação arbórea nativa e pastagens no pantanal sul-mato-grossense. Revista Brasileira de Ciência do Solo, v. 35, n. 2, p. 613-622, 2011. https://doi.org/10.1590/S0100-06832011000200030

FERNANDES, A. R.; MATOS, G. S. B.; CARVALHO, J. G. Deficiências nutricionais de macronutrientes e sódio em mudas de pupunheira. Revista Brasileira de Fruticultura, v. 35, n. 4, p.1178-1189, 2013. https://doi.org/10.1590/S0100-29452013000400029

FOLHES, M. T.; FISCH. G. Caracterização climática e estudo de tendências nas séries temporais de temperatura do ar e precipitação em Taubaté - SP. Revista Ambiente \& Água, v. 1, n. 1, p. 61-71, 2006. https://dx.doi.org/10.4136/ambi.agua.6

FREITAS, L. et al. Indicadores da qualidade química e física do solo sob diferentes sistemas de manejo. Revista Unimar: Ciências, v. 26, n. 1, p. 8-25, 2017.

GUARESCHI, R. F.; PEREIRA, M. G.; PERIN, A. Deposição de resíduos vegetais. matéria orgânica leve. estoque de carbono e nitrogênio e fósforo remanescente sob diferentes sistemas de manejo no cerrado goiano. Revista Brasileira de Ciência do Solo, v. 36, p. 909-920, 2012. http://dx.doi.org/10.1590/S0100-06832012000300021

IWATA, B. F.; LEITE, L. F. C.; ARAÚJO, A. S. F.; NUNES, L. A. L.; GEHRING, C.; CAMPOS, L. P. Sistemas agroflorestais e seus efeitos sobre os atributos químicos em Argissolo Vermelho-Amarelo do cerrado piauiense. Revista Brasileira de Engenharia Agrícola e Ambiental, v. 16, n. 7, p. 730-738, 2012. http://dx.doi.org/10.1590/S141543662012000700005

KLUTHCOUSKI, J.; CORDEIRO, L. A. M.; CECCON, G.; OLIVEIRA, P. Braquiária na agropecuária brasileira: uma história de sucesso. In: CECCON. G. Consórcio milhobraquiária. Brasília, DF: Embrapa Agropecuária Oeste, 2013. 175 p.

LOPES, E. L. N. et al. Microbial biomass and soil chemical properties under different land use systems in northeastern Pará. Revista Brasileira de Ciência do Solo, v. 35, n. 4, p. 1127 1139, 2011. http://dx.doi.org/10.1590/S0100-06832011000400006

LOSS, A. et al. Fertilidade do solo e matéria orgânica em Vertissolo e Argissolo sob cobertura florestal e pastagem. Comunicata Scientiae, v. 5, n. 1, p. 1-10, 2014. https://doi.org/10.14295/cs.v5i1.406

LOURENTE, E. R. P. et al. Atributos microbiológicos. químicos e físicos de solo sob diferentes sistemas de manejo e condições de cerrado. Pesquisa Agropecuária Tropical, v. 41, n. 1, p. 20-28, 2011. http://dx.doi.org/10.5216/pat.v41i1.8459 
NATIONAL RESEARCH COUNCIL (U.S.). Soil and water quality: and agenda for agriculture. Washington, DC: National Academy Press, 1993. 542 p.

MAIA, C. M. B. F. et al. Soil Organic Matter: Chemical and Physical Characteristics and Analytical Methods. A Review. Current Organic Chemistry, v. 17, n. 24, p. 29852990, 2013. https://doi.org/10.2174/13852728113179990123

MONTANARI, R.; LIMA, E. S.; LOVERA, L. H.; FERRARI, S.; QUEIROZ, H. A. Correlação dos componentes vegetativos da cultura da pupunha e dos atributos químicos do solo. $\begin{array}{llllllll}\text { Agricultura Neotropical, } & \text { v. } 3, \quad \text { n. } 2, & \text { p. }\end{array}$ https://doi.org/10.32404/rean.v3i2.857

MORAIS, E. R. C. et al. Indicadores da qualidade química do solo em áreas cultivadas com mamoeiro irrigado. Revista Brasileira de Engenharia Agrícola e Ambiental, v. 19, n. 6, p. 587-591, 2015. https://doi.org/10.1590/1807-1929/agriambi.v19n6p587-591

NETTO, I. T.; KATO, E.; GOEDERT, W. J. Atributos físicos e químicos de um Latossolo Vermelho-Amarelo sob pastagens com diferentes históricos de uso. Revista Brasileira de Ciência do Solo, v. 33, p. 1441-1448, 2009. http://dx.doi.org/10.1590/S010006832009000500034

PEREIRA, M. G.; LOSS, A.; BEUTHER, S. J.; TORRES, J. L. R. Carbono. matéria orgânica leve e fósforo remanescente em diferentes sistemas de manejo do solo. Pesquisa Agropecuária Brasileira, v. 45, n. 5, p. 508-514, 2010. http://dx.doi.org/10.1590/S0100204X2010000500010

PORTUGAL, A. F.; COSTA, O. D. V.; COSTA, L. M. Propriedades físicas e químicas do solo em áreas com sistemas produtivos e mata na região da zona da mata mineira. Revista Brasileira de Ciência do Solo, v. 34, p. 575-585, 2010. http://dx.doi.org/10.1590/S010006832010000200032

RAIJ, B. V.; ANDRADE, J. C.; CANTARELLA, H.; QUAGGIO, J. A. Análise química para avaliação da fertilidade de solos tropicais. Campinas: Instituto Agronômico, 2001.

RAIJ, B. V.; CANTARELA, H.; QUAGGIO, J. A.; FURLANI, A. M. C. Recomendações de adubação e calagem para o Estado de São Paulo. Boletim técnico 100. 2. ed. Campinas: Instituto Agronômico; Fundação IAC, 1997.

RIBEIRO, J. C. et al. Litterfall dynamics and nutrient cycling in an experimental plantation of peach palm (Bactris gasipaes Kunth). Floresta e Ambiente, v. 27, n. 2, 2020. http://dx.doi.org/10.1590/2179-8087.021018

SANTOS, H. G.; JACOMINE, P. K. T.; ANJOS, L. H. C.; OLIVEIRA, V. A.; LUMBREARAS, J. F.; COELHO, M. R.; ALMEIDA, J. A.; ARAÚJO-FILHO, J. C.; OLIVEIRA, J. B.; CUNHA, T. J. F. Sistema Brasileiro de Classificação de Solos. 5. ed. Brasília, DF: Embrapa, 2018.

SCHIAVO, J. A.; ROSSEL, J. R.; PEREIRA, M. G.; SALTON, J. C. Índice de manejo de carbono e atributos químicos de Latossolo Vermelho sob diferentes sistemas de manejo. Pesquisa Agropecuária Brasileira, v. 46, n. 10, p. 1332-1338, 2011. http://dx.doi.org/10.1590/S0100-204X2011001000029

SILVA, G. R.; LIMA SENA, W.; SILVA JÚNIOR, M. L. Carbono e nitrogênio da biomassa microbiana como indicadores ambientais de um Latossolo Amarelo sob diferentes sistemas de manejo, Marituba, Pará. Revista de Ciências Agrárias, v. 48, n. 1, p. 71-84, 2007. 
SILVA, D. C. et al. Atributos do solo em sistemas agroflorestais, cultivo convencional e floresta nativa. Revista de Estudos Ambientais, v. 13, n. 1, p. 77-86, 2011.

SOUZA, M. C. S.; PIÑA-RODRIGUES, F. C. M. Desenvolvimento de espécies arbóreas em sistemas agroflorestais para recuperação de áreas degradadas na floresta ombrófila densa, Paraty, RJ. Revista Árvore, v. 1, n. 37, p. 89-98, 2013. https://doi.org/10.1590/S010067622013000100010

STATISTICAL ANALYSIS SYSTEM INSTITUTE. Procedure guide for personal computers. Version 5. Cary, 1999. 1 CD Rom.

TAVARES-FILHO, J.; FERREIRA, R. R. M.; FERREIRA, V. M. Fertilidade química de solo sob pastagens formadas com diferentes espécies nativas e com Brachiaria decumbens manejadas com queimadas anuais. Semina: Ciências Agrárias, v. 32, supl. 1, p. 17711782, 2011. https://dx.doi.org/10.5433/1679-0359.2011v32Suplp1771 